\title{
Multiple reproductives in nests of the Neotropical termite Constrictotermes cyphergaster (Isoptera, Termitidae, Nasutitermitinae)
}

Hélida Ferreira da Cunha ${ }^{1}$

Divino Brandão ${ }^{1}$

\begin{abstract}
Constrictotermes cyphergaster (Silvester, 1901) builds arboreal nests in Brazilian Cerrado stricto sensu, which are frequently cohabited by inquilines termites and by termitophiles. In a study made at the Parque Estadual da Serra de Caldas Novas, Goiás, Brazil, there were four nests with multiple reproductives, and secondary reproductives were found in 26 nests. Nymphs of Inquilinitermes were more abundant $(9,47 \%)$ than nymphs of C. cyphergaster $(0,78 \%)$.
\end{abstract}

KeYworDs. Constrictotermes cyphergaster; Inquilinitermes; multiple reproductives; termite.

\section{INTRODUCTION}

Constrictotermes cyphergaster (Silvestri, 1901) builds arboreal nests in Brazilian Cerrado stricto sensu (MATHEws 1977; Constantino \& Costa-Leonardo 1997), being also found in the region of Caatinga vegetation (GodinHo et al. 1989). They are important due their abundance and for sheltering other species of inquiline termites of the genus Inquilinitermes and a great number of termitophiles (ARAúJo 1970).

In several Isoptera groups, when one of the primary reproductive dies or becomes old, they are replaced by secondary reproductives that can have several origins: "adultoids" are derived from the imagoes, "nymphoids" are derived from nymphs and retain the wing buds, "ergatoids" are derived from workers and have no evidence of wing buds (NoIROT 1969; WiLSON 1971; BRIAN 1979; Costa-LeONARDo et al. 1996; THORNe 1996; MyLes 1999). If any of these reproductive types differentiates within a colony while primaries ones are still alive and reproducing, are called supplementary (THORNE 1996) and if they developed after primaries die, they will be replacement reproductives (Myles 1999). In "higher" termites, the factors that trigger supplementary determination are: greater population diffusion, perturbations in rates of population growth, seasons, newly discovered resources items, or architectural extensions of the colony (polycalism) (MYLES 1999).

Most of species of termites are monogynous - colonies with only one queen, however, polygynic colonies - with multiple queens - occur in four subfamilies of Termitidae:
Apicotermitinae, Termitinae, Nasutitermitinae and Macrotermitinae (THORNe 1982, 1985). Polygyny is a condition in which multiple fecund queens coexist and are cared by the non-reproductive castes within a single colony (THORNE 1985). An ecological advantage of the polygyny may be that increased egg production yields a faster expansion of the colony size, at least in habitats with an adequate food supply (THORNE 1982; Darlington 1988). According to Keller (1998), most of the species probably form both single and multiple queen colonies, hence, the species should better be classified on a monogynypolygyny "continuum" with either the proportion of polygyne colonies or the average queen number per colony as a measure of the "level' of the polygyny.

In this study, aspects of the reproduction of $C$. cyphergaster, like the occurrence of multiple reproductives (primary and supplementary) and the proportion of nymphs between $C$. cyphergaster and Inquilinitermes spp., are discussed.

\section{MATERIALAND METHODS}

Data were collected in the Parque Estadual da Serra de Caldas Novas (PESCAN), State of Goiás, Brazil, that has a 125 $\mathrm{km}^{2}$ area, maximum altitude of $1.043 \mathrm{~m}$, with several forms of Cerrado vegetation (Almeida \& SARMENTo 1998). In a Cerrado stricto sensu area on highland top, 40 nests of $C$. cyphergaster were collected, from January to July 1999, varying from 16 to 55 $\mathrm{cm}$ of larger diameter and 9 to $49 \mathrm{~cm}$ of smaller diameter, that represents practically the whole of range sizes nests existent in

1. Departamento de Biologia Geral, Instituto de Ciências Biológicas, Universidade Federal de Goiás. Caixa Postal 131, $74001-970$ Goiânia - GO, Brasil. E-mail: hfcunha@icb1.ufg.br; dbrandao@icb1.ufg.br 
the area. Each nest was removed from the support tree, put in plastic sacks and etherized for killing the termites. The nests were opened and examined searching for the royal pair. After, the nests were fragmented in small pieces, taking care to avoid crushing the individuals. The nest material was homogenized and subsamples of $5 \%$, in relation to the total volume, were collected for counting the number of primary and secondary reproductives and nymphs. King and queen, when found, were collected separately and stored in alcohol 80\% (CunHa 2000).

\section{RESULTS}

Some trees held two nests connected by an external gallery, suggesting polycalism. In two of these trees, the two nests connected were collected and in other two trees were just collected one of the nests. All those nests had secondary reproductives and only one had a royal pair.

There is no distinct royal cell inside the nest. The royal pair and the eggs were found close, in the inner part of the nest, close to the stem of the support tree, where the walls are thicker and compacted. In one nest, the royal pair was found hiding in the reentrances of the bark of the tree. There is a notable sexual dimorphism: the queen is physogastric, larger and lighter than the king, and among the physogastric queens, a slight size difference was observed. In four distinct nests were found four kings, two, three and two queens, respectively (Table 1), all queens physogastrics and with slight size differences. This fact was never registered for $C$. cyphergaster. From 40 nests collected, one of the primary reproductives (king or queen) was found in 17 nests, and just in 5 nests, it was found a royal pair (Table 1).

Secondary reproductives occurred in 26 nests, and primary reproductives were found in 14 these (Table 1). Secondary reproductives are morphologically very similar to the king, although darker and slender. They have big compound eyes, hair body and small wing buds. None of these were physogastric or had a dilated abdomen.

Nymphs of $C$. cyphergaster appeared in 20 nests. Twentythree of the 40 nests collected were cohabited by Inquilinitermes. I. fur had nymphs in 4 nests and I. microcerus had in 14 nests (Table 1). The proportion of nymphs, in relation to the all individuals sampled was $0,78 \%$ for $C$. cyphergaster and $9,47 \%$ for Inquilinitermes. Nymphs with wing buds occurred in the three species, along the collecting (January to June 1999), in nests larger then or equal to $33,1 \mathrm{~cm}$ of larger diameter. Nymphs of C. cyphergaster are bigger, brownish, with red and big eyes, and nymphs of Inquilinitermes are smaller, whitish, with whitish and small eyes, both types showed an individual size variation. In July, the wing buds were larger.

\section{DISCUSSION}

The fact of the royal pair had not been found in all the nests, does not mean that they were absent; might just had been a consequence of the sampling method, because they might had fled or been crushed during the collection or had not been subsampled. Although the queens had not been weighed, their physogastry was related to the colony size (CunHA 2000). The queen physogastric development is probably a good measure of fecundity (MyLES 1999). According to this author, with the evolution of physogastry, developmental constraints have skewed fecundity such that primary reproductives have greater fecundity than nymphoids, which have greater fecundity than ergatoids. Maybe this affirmation can confirm the absence of physogastry in secondary reproductives and nymphs. In this study, some nests had multiple primary reproductives, others had also secondary reproductives (Table 1), indicating that the death of the fertile female did not cause the death of the colony. Some works registered multiple reproductives in nests with different sizes, where all of the queens were physogastrics and had the same size, and were inside in the same royal cell (THORNE 1982, 1985; DARLINGTON 1988).

The secondary reproductives referred in this study, can be either supplementary or replacement reproductives, and it is possible that they can be neotenics, because seemly they are not derived from alates, although in the review made by MYLES (1999) it did not have records about neotenics reproductives for Constrictotermes. Costa-Leonardo et al. (1999) found Coptotermes havilandi replacement reproductives in two nests (subsidiary and satellite), called preneotenics by these authors, occurring together with the royal pair and concluded that they were the most immediate substitutive reproductives source. Costa-Leonardo et al. (1999) indicated that primary reproductives can prevent the maturation of neotenics, but do not inhibit their formation, and these preneotenics never disperse from their own colony. Lenz et al. (1988) stated that the regular presence of non-functional neotenics in colonies headed by primaries, is a safeguard against potential interruptions of brood production due to loss or failure of one or both members of the royal pair. In spite of the fact that neotenics have not been registered among Inquilinitermes, MyLes (1999) suggested that inquilines would be subject to occasional invasion and elimination of primary reproductives by the host species, therefore, opportunities for replacements might occur regularly.

Alates were not found in this study, but GodinHo et al. (1989) registered the occurrence of alates in $28 \%$ of the nests in the rainy season, from August to October in 1985. According to Shellman-Reeve (1997), inquiline alates may disperse preferentially to large-sized, highly populated colonies of the host species, and thus escape detection by the host while initiating a nest within the host's nest wall.

Acknowledgements. We thank the Environmental Agency of Goiás for authorize the sampling execution in PESCAN. To the colleagues $\mathrm{L}$. O. Silva, D. C. Andrade e K. Espírito Santo Filho for the help in the field work. To Dr. A. M. Costa-Leonardo (UNESP) for the valuable suggestions. 
Table 1. Number of kings, queens, supplementary reproductives and nymphs of C. cyphergaster, Inquilinitermes fur and I. microcerus per 5\% sub sample of each nest

\begin{tabular}{|c|c|c|c|c|c|}
\hline \multicolumn{4}{|c|}{ C. cyphergaster } & \multirow{2}{*}{$\begin{array}{c}\text { I. fur } \\
\text { Nymph }\end{array}$} & \multirow{2}{*}{$\begin{array}{c}\text { I. microcerus } \\
\text { Nymph }\end{array}$} \\
\hline King & Queen & Supplementary & Nymph & & \\
\hline 1 & 1 & 0 & 0 & 0 & 0 \\
\hline 4 & 1 & 8 & 0 & 0 & 15 \\
\hline 0 & 1 & 1 & 44 & 21 & 0 \\
\hline 0 & 0 & 4 & 69 & 0 & 0 \\
\hline 0 & 1 & 0 & 0 & 0 & 0 \\
\hline 0 & 1 & 4 & 3 & 0 & 0 \\
\hline 0 & 2 & 6 & 55 & 0 & 40 \\
\hline 0 & 0 & 8 & 38 & 0 & 0 \\
\hline 0 & 1 & 0 & 0 & 0 & 0 \\
\hline 0 & 0 & 1 & 9 & 0 & 13 \\
\hline 0 & 1 & 1 & 0 & 0 & 35 \\
\hline 0 & 1 & 0 & 0 & 0 & 0 \\
\hline 0 & 0 & 0 & 37 & 0 & 30 \\
\hline 0 & 1 & 24 & 0 & 0 & 0 \\
\hline 0 & 1 & 1 & 0 & 0 & 0 \\
\hline 0 & 1 & 1 & 0 & 0 & 0 \\
\hline 0 & 1 & 2 & 25 & 0 & 54 \\
\hline 0 & 0 & 8 & 25 & 0 & 12 \\
\hline 0 & 1 & 7 & 28 & 20 & 0 \\
\hline 0 & 0 & 0 & 28 & 0 & 31 \\
\hline 0 & 0 & 3 & 27 & 0 & 37 \\
\hline 0 & 0 & 0 & 26 & 13 & 0 \\
\hline 1 & 1 & 13 & 1 & 0 & 0 \\
\hline 0 & 0 & 1 & 0 & 0 & 0 \\
\hline 1 & 1 & 0 & 19 & 0 & 42 \\
\hline 0 & 0 & 1 & 0 & 0 & 0 \\
\hline 0 & 0 & 7 & 0 & 0 & 0 \\
\hline 0 & 1 & 0 & 0 & 0 & 0 \\
\hline 1 & 1 & 6 & 26 & 0 & 9 \\
\hline 0 & 0 & 8 & 33 & 42 & 0 \\
\hline 0 & 3 & 4 & 69 & 0 & 95 \\
\hline 0 & 2 & 1 & 0 & 0 & 9 \\
\hline 0 & 0 & 3 & 30 & 0 & 0 \\
\hline 0 & 0 & 8 & 0 & 0 & 0 \\
\hline 0 & 1 & 0 & 12 & 0 & 30 \\
\hline 0 & 1 & 0 & 0 & 0 & 0 \\
\hline 0 & 0 & 4 & 0 & 0 & 0 \\
\hline
\end{tabular}

\section{REFERENCES}

Almeida, A. F. \& F. N. M. Sarmento. (coordinators). 1998. Parque Estadual da Serra de Caldas - Plano de Manejo. Goiânia, CTE (Centro Tecnológico de Engenharia Ltda), FEMAGO Fundação Estadual do Meio Ambiente.

AraúJo, R. L. 1970. Termites of the Neotropical Region, p. 527-576 In: Krishna, K. \& F. M. Weesner (eds.). Biology of Termites. Vol. II. New York, Academic Press.

BRIAN, M. V. 1979. Caste differentiation and division of labor, p. 121 222. In: Hermann, H. R. (ed.) Social insects. Vol. I. New York, Academic Press.
Constantino, R. \& A. M. Costa-Leonardo 1997. A new species of Constrictotermes from Central Brazil with notes on the mandibular glands of workers (Isoptera; Termitidae: Nasutitermitinae). Sociobiology 30 (2): 213 - 223.

Costa-Leonardo, A. M.; R. C. Barsotti \& C. R. R. Camargo-Dietrich 1999. Review and update on the biology of Coptotermes havilandi (Isoptera, Rhinotermitidae). Sociobiology 33 (3): 339-356.

Costa-Leonardo, A. M.; R. C. Barsotti \& H. X. Soares 1996. Multiple nymphoid reproductives in the nests of the neotropical termite, Armitermes euamignathus (Isoptera, Termitidae, Nasutitermitinae). Sociobiology 28 (2): 197-205.

Cunha, H. F. 2000. Estudo de colônias de Constrictotermes 
cyphergaster do Parque Estadual da Serra de Caldas Novas GO. Universidade Federal de Goiás, 57 p. (Tese, Mestrado).

Darlington, J. P. E. C. 1988. Multiple reproductives in nests of Macrotermes herus (Isoptera: Termitidae). Sociobiology 14 (2): 347-351.

Godinho, A. L.; L. V. Lins; T. A. GontiJo \& D. J. Domingos.1989. Aspectos da ecologia de Constritotermes cyphergaster (Termitidae: Nasutitermitinae) em cerrado, Sete Lagoas, MG. Revista Brasileira de Biologia 49 (3): 703 - 708.

KelLeR, L. 1998. Queen lifespan and colony characteristics in ants and termites. Insectes Sociaux 45: 235-246.

Lenz, M.; R. A. BarRet \& L. R. Miller. 1988. Mechanisms of colony reestablishment after orphaning in Coptotermes lacteus (Froggatt) (Isoptera; Rhinothermitidae). Sociobiology 14 (1): 245-268.

Mathews, A. G. A. 1977. Studies on termites from the Mato Grosso State, Brazil. - Rio de Janeiro. Academia Brasileira de Ciências, $267 \mathrm{p}$.

Myles, T. G. 1999. Review of secondary reproduction in termites (Insecta: Isoptera) with comments on its role in termite ecology and social evolution. Sociobiology 33 (1): 01-91.

Noirot, C. 1969. Formation of castes in the higher termites p. 311-350 In: Krishna, K. \& F. M. Weesner (eds.). Biology of Termites. Vol. I. New York, Academic Press.

Shellman-Reeve, J. S. 1997. The espectrum of eusociality in termites p. 52-93 In: Choe, J. C. \& B. J. Crespi (eds.) The evolution of social behavior in insects and arachnids. Cambridge University Press.

Thorne, B. L. 1982. Polygyny in termites: multiple primary queens in colonies of Nasutitermes corniger (Motschuls) (Isoptera: Termitidae). Insectes Sociaux 29 (1): 102-117.

THORNE, B. L. 1985. Termite polygyny: the ecological dynamics of queen mutualism p. 323-341. In: Hölldobler, B. \& M. Lindauer (eds.) Experimental behavioral and sociobiology. New York, G. Fisher Verlag-Stuttgart.

Thorne, B. L. 1996. Termite Termitology. Sociobiology 28 (3): 253 263.

WiLson, E. O. 1971. The Insect Societies. Cambridge Harvard University Press, 548p. 